AGRICULTURE AND BIOLOGY JOURNAL OF NORTH AMERICA

ISSN Print: 2151-7517, ISSN Online: 2151-7525

(C) 2011, ScienceHuß, http://www.scihub.org/ABJNA

\title{
Effect of seed priming on dry matter, seed size and morphological characters in wheat cultivar
}

\author{
Leila Yari ${ }^{1}$, Ashkan Abbasian ${ }^{1}$, Bita Oskouei $^{1}$ and Hossein Sadeghi ${ }^{1}$ \\ ${ }^{1}$ Seed and Plant Certification and Registration Research Institute,Karaj, Iran \\ E-Mail: yaril2001@yahoo.com
}

\begin{abstract}
In order to evaluate the effect of seed priming on dry matter, seed size ,and morphological characters of wheat, a 2-year experiment was conducted at seed and plant certification \& registration Institute (SPCRI) in Karaj, Iran, from 2008-2010. Two cultivars (Azar-2, Sardare-101) $\times$ four priming media and control (unsoaked) were used in this experiment in field. Seeds were primed for 12 hour and $20^{\circ} \mathrm{C}$ in four priming media (PEG 10\%, $\mathrm{KCl} 2 \%, \mathrm{KH}_{2} \mathrm{PO}_{4} \mathrm{0} / 5 \%$, distilled water) and control. Results of comparing means of cultivar showed that maximum seed length ,awn length was observed in sardari-101.Seed priming treatment had significant effects on leaf area in plant, dry matter ,harvest index and awn length.Incondactive interaction between seed priming treatment $\times$ cultivar, maximum dry matter and leaf area in plant was obtained in Azar-2x $\mathrm{KCl} 2 \%$ and sardari-101 $\times \mathrm{KH}_{2} \mathrm{PO}_{4} 0 / 5 \%$ respectively. The most harvest index $(\mathrm{HI})$ was observed in sardari-101 $\times \mathrm{KH}_{2} \mathrm{PO}_{4} 0 / 5 \% \times$ second year.Results of interaction between year $\times$ cultivar showed that maximum spike length was achieved from sardari-101 $\times$ second year. In comparing of seed priming treatments on $\mathrm{HI}$, not significant different among PEG 10\%,water and control. Seed width, seed diameter, spike length ,seed length and awn length had significant different in second year( $p<0.01)$. Inconculusion the result of the study have shown that seed priming treatments had different effect on characters in this experiment.
\end{abstract}

Keyword: wheat cultivar ,Seed priming, dry matter, seed size and Harvest Index.

\section{INTRODUCTION}

Pre-sowing seed treatments seems to be a promising technique to raise successful crop in arid and semiarid tropics. Seed priming enhances speed and uniformity of germination(Khalil et al.,2010;Khan et al.,2008), and induces several biochemical changes in the seed that are required to start the germination process such as breaking of dormancy, hydrolysis or mobilization of inhibitors, imbibitions and enzyme activation(Asgedom and Becker,2001).The resulting improved stand established can reportedly increase the drought tolerance, reduce pest damage and increase crop yield in cereals and legumes(Harris et al.,1999;Mussa et al.,1999; Harris et al.,2000;Khan et al.,2005).Seed priming with $\mathrm{P}_{2} \mathrm{O}_{5}$ solution enhanced days to emergence,anthesis and increased dry matter(DM) production compared with nonprimed(control)(Shad et al.,2010) .Primed crops grew more vigorously, flowered earlier and yield higer.In wheat, researchers have recorded mean yield increases in six large series of on-farm trials of 5\%to 36\%( Harris et al.,2001).Seed priming with potassium salts(1\%)for $18 \mathrm{~h}$ increased wheat yield under dry land condition(paul and choudhury,1991).
Dell-Aquila and Tritto (1990) reported that primed seeds emerged $12 \mathrm{~h}$ earlier than non primed seeds. This may be due to increase in activity of enzymes such as amylase, protease and lipase which have great role in break down of macromolecules for growth and development of embryo that ultimately resulted in early and higher seedling emergence. Seed enhancement with cytokinins, increasing germination rate, seedling growth and improved grain yield in salt stressed wheat plants(Iqbal et al.,2006). Osmohardening with $\mathrm{KCL}$ and $\mathrm{CaCl}_{2}$ improved germination and emergence, allometry,kernel yield, and its quality ,Faster and uniform emergence was due to improved alpha-amylase activity, which increased the level of soluble sugars in the primed kernels. A positive correlation between mean emergence time and days to heading, while a negative one between kernel yield and harvest index( Farooq et al.,2006).On-farm seed priming with water(hydro priming) in maize, rice and chickpea caused that seed emergence faster, improved establishment, crops grew more vigorously ,flowered earlier and yielded higher(Harris et al .,1999).Mung bean cultivars seed were primed for 6 and 12 hours in different solution of water and osmotic solution of 
$\mathrm{PEG}_{8000}$ equivalent to $0,-0.2,-0.5$ and $-1.1 \mathrm{MPa}$. A decrease in osmotic potential in treatment solution from 0 to $-1.1 \mathrm{MPa}$ resulted in better performance, in terms of yield and components. It was concluded that hydro-primed and/or seed primed in $-0.5 \mathrm{MPa}$ osmotic potential solution of PEG were better in pheonology and yield than all other treatments(Khan et al.,2008). Rice seed priming with hydro priming ,osmohardening with $\mathrm{KCL}$ or $\mathrm{CaCl}_{2}$ and ascorbat ,Osmohardening with $\mathrm{CaCl}_{2}$ resulted in the best performance. Osmohardening with $\mathrm{CaCl}_{2}$ produced more kernel yield, straw yield and harvest index with compare control. Seed were given different priming treatments like hydro priming, chilling, kinetin, $\mathrm{CaCl}_{2}$ center dot $\mathrm{H}_{2} \mathrm{O}$ and controlled. The results revealed that generally all treatments except hydro priming increasing the morphological growth of the seedling showed a significant difference compared to control, However seed priming treatments tend to alleviate the adverse effects of salinity(Rafiq et al.,2006). Due to the priming treatments, Primed crops grew more vigorously, flowered earlier, increase in leaf area index , dry matter accumulation and ultimately more seed yield .Increased leaf area duration due to early emergence by priming might have enhanced yield by increasing the amount of light intercepted by canopy throughout the season(Henckel,1964;Scotte et al., 1973,Harris et al.,2001). Murungu et al.(2004) reported that Effects of on- farm seed priming on consecutive daily sowing occasions on the emergence and growth of maize in semi-arid Zim babwe,There was little effect of priming on growth, time to flowering and maturity or yield of plants .

\section{MATERIALS AND METHODS}

A 2-year experiment was conducted at seed and plant certification \& registration Institute (SPCRI) in Karaj, Iran, from 2008-2010. Experimental design was a two-factor factorial wheat cultivar (Azar-2, sardare -101), priming media (PEG $10 \%, \mathrm{KCl} 2 \%$, $\mathrm{KH}_{2} \mathrm{PO}_{4} \mathrm{O} / 5 \%$, distilled water plus a check) using randomized complete blocks with four replications. Seed was fully immersed in priming media at $20^{\circ} \mathrm{C}$ temperature, duration of $12 \mathrm{~h}$. All seed was then rinsed thoroughly with distilled water and lightly hand dried using blotting paper. Then allowed to dry on paper towels at room temperature $\left(24^{\circ} \mathrm{C}\right)$ until seed water content was $120 \mathrm{~g} \mathrm{~kg}^{-1}$ as measured with a grain moisture meter. Seed was stored at $8+2{ }^{\circ} \mathrm{C}$. Planting rate was 200 seeds row-1 per individual 5m-long plot. A four-row deep-furrow with $35 \mathrm{~cm}$ row spacing was used for planting in summer fallow. A 13-cm-deep soil layer covered the seed. Average annual precipitation during the experiment was 159 $\mathrm{mm}$ and $216 \mathrm{~mm}$ for 2009 and 2010.In flowering stage leaf area and dry matter was measured. Leaf area was measured by using leaf area meter(LI3100).for measuring dry matter , 5 plants from each plot, selected. Following drying at oven in $75^{\circ} \mathrm{C}$ for 48 hours. The dry weight was recorded (digital scale, $0.01 \mathrm{~g}$ accuracy)for each treatment. Finally whole plots were harvested with laborer by using hand. Characters such as Seed width, seed diameter and seed length ,spike length and awn length was measured. Experimental data were analyzed using SAS (statistical software, SAS institute, 2002) and treatment means were compared using Duncan's multiple range test at $5 \%$ level of probability.

\section{RESULTS AND DISCUSSION}

The maximum seed length, awn length and leaf area in plant was observed in sardari-101. Seed width and awn length $(p<0.05)$ were significantly affected by seed priming treatment. The maximum and minimum seed width was attained from applied $\mathrm{KH}_{2} \mathrm{PO}_{4} \quad 0 / 5 \%$ and $\mathrm{KCL} 2 \%$ priming respectively .The maximum and minimum awn length was obtained in PEG 10\% and $\mathrm{KH} 2 \mathrm{PO} 4 \quad 0 / 5 \%$ respectively( Table-1).Seed length, leaf area in plant, dry matter $(p<0.01)$ and awn length $(p<0.05)$ were significantly affected by cultivar(Table-2). Interaction effects of priming treatment $\times$ cultivar on leaf area in plant and dry matter was significant $(p<0.05)$. The highest leaf area in plant and dry matter was obtained from sardri-101× $\mathrm{KH}_{2} \mathrm{PO}_{4} \mathrm{O} / 5 \%$ (1339/5 $\left.\mathrm{cm}^{2}\right)$ in average and Azar-2× KCL $2 \%(42 / 4 \mathrm{~g}$ in average),respectively( Figure-1,2). In this investigate priming seed treatments with $\mathrm{KCL} 2 \%$ had different effect on dry matter in cultivars, meanwhile in sardari -101 cultivar,reduced dry matter in flowering stage .Due to the priming treatments ,seed emergence faster, improved establishment, crops grew more vigorously and increased leaf area duration. Due to early emergence by priming might have enhanced yield by increasing the amount of light intercepted by canopy throughout the season(Henckel,1964;Scotte et al.,1973,Harris et al.,2001).These findings are in line with Farooq et al.(2006) who states that osmohardening with $\mathrm{KCl}$ and $\mathrm{CaCl}_{2}$ improved germination and emergence,allometry,kernel yield and its quality, greater efficiency of osmohardening with $\mathrm{CaCl}_{2}$ and $\mathrm{KCl}$ is possibly related to the osmotic advantage that both $\mathrm{k}^{+}$and $\mathrm{Ca}^{2+}$ have an improving cell water 
statuse,and also in that they act as cofactors in the activities of numerous enzymes(Taiz and Zeiger,2002).. Interaction effect among cultivarx year was significant on spike length .The maximum ear length was obtained in sardari $-101 \times$ second year $(11 / 6 \mathrm{~cm}$ in average),But seed priming treatment not significant effect on spike length .These results agree with shad et al.(2010) who reported that priming of wheat seed in $\left(\mathrm{p}_{2} \mathrm{O}_{5}\right)$ enhanced day to emergence, anthesis and increased dry matter (DM) production compared with non primed (control) and priming had not significant effect on spike length. In conclusion wheat seed priming with $\mathrm{KH}_{2} \mathrm{PO}_{4} \mathrm{O} / 5$ $\%$ is better treatment to increase seed with, leaf area and dry matter. PEG $10 \%$ treatment just had positive effect on awn length, meanwhile PEG $10 \%$ had negative effect on leaf area and dry matter weight in plant. Effects of year, treatment, treat $x$ year and cultivar $\times$ treat $x$ year was significant on harvest index $(p<0.01)$. Results of interaction effects of priming treatment $\times$ cultivar $\times$ year showed that maximums and minimum $\mathrm{HI}$ was attained from sardari $-101 \times \mathrm{KH}_{2} \mathrm{PO}_{4}$ 0/5 \%× second year(49/56\% in average) and sardari $-101 \times$ PEG $10 \% \times$ second year respectively(figure -3,4). The findings are in line with Harris et al.(2001) who reported that priming seed improve germination, crops grew more vigorously ,flowered earlier and yielded higer.Also Farooq et al.(2006)reported that osmohardening with
$\mathrm{KCL}$ and $\mathrm{CaCl}_{2}$ increased grain yield, straw and harvest index in rice plant.Thesersults agree with who reporthed seed priming improve stand establishment creals and legume, Also increased yield and tolerance in dry condition effects of year on seed with ,spike length, seed diameter seed length ,awn length was significant $(p<0.01)$. Meanwhile year effects of leaf area and dry matter weight was not significant . maximum seed with, seed diameter, awn length was observed in first year. But maximum spike length and harvest index was obtained in second year( table 3).There was significant difference and positive correlation was observed between leaf area and dry matter in plant in flowering stage $(p<0.01)$.Also positive correlation was observed among leaf area in plant , $\mathrm{HI}$ and dry matter.Inconclusion the result of the study have shown that, seed priming treatment had different effect on characters studied in this experiment. Recommendation that similar experiment to repeat in different place by using different crop in our country.

Table-1. Means comparison of characteristics by using Duncan multiple test in seed priming treatments

\begin{tabular}{|c|c|c|c|c|c|c|c|}
\hline $\begin{array}{c}\text { Seed priming } \\
\text { treatments }\end{array}$ & $\begin{array}{r}\text { Seed } \\
\text { width }\end{array}$ & $\begin{array}{r}\text { Seed } \\
\text { diameter }\end{array}$ & $\begin{array}{r}\text { Seed } \\
\text { length }\end{array}$ & $\begin{array}{r}\text { Spike } \\
\text { length }\end{array}$ & $\begin{array}{r}\text { Awn } \\
\text { length }\end{array}$ & $\begin{array}{c}\text { Leaf area } \\
\text { in }\end{array}$ & $\begin{array}{c}\text { Dry } \\
\text { plant } \\
\left(\mathrm{cm}^{2}\right)\end{array}$ \\
$\begin{array}{c}\text { matter in } \\
\text { plant (g) }\end{array}$ \\
\hline $\mathrm{PEG} 10 \%$ & $2.97 \mathrm{~b}$ & $2.75 \mathrm{a}$ & $7.34 \mathrm{a}$ & $10.56 \mathrm{a}$ & $5.49 \mathrm{a}$ & $711.47 \mathrm{~b}$ & $26.15 \mathrm{~b}$ \\
\hline $\mathrm{KH}_{2} \mathrm{PO}_{4} 0 / 5 \%$ & $3.03 \mathrm{ab}$ & $2.76 \mathrm{a}$ & $7.41 \mathrm{a}$ & $10.65 \mathrm{a}$ & $5.05 \mathrm{~b}$ & $1039.79 \mathrm{a}$ & $39.70 \mathrm{a}$ \\
\hline $\mathrm{KCL} \%$ & $2.99 \mathrm{ab}$ & $2.74 \mathrm{a}$ & $7.44 \mathrm{a}$ & $10.58 \mathrm{a}$ & $5.20 \mathrm{ab}$ & $896.77 \mathrm{a}$ & $30.21 \mathrm{~b}$ \\
\hline Distilled water & $3.10 \mathrm{a}$ & $2.77 \mathrm{a}$ & $7.40 \mathrm{a}$ & $10.72 \mathrm{a}$ & $5.30 \mathrm{ab}$ & $1037.49 \mathrm{a}$ & $35.55 \mathrm{a}$ \\
\hline control & $3.00 \mathrm{ab}$ & $2.74 \mathrm{a}$ & $7.3 \mathrm{a}$ & $10.46 \mathrm{a}$ & $5.15 \mathrm{ab}$ & $937.49 \mathrm{a}$ & $36.6 \mathrm{a}$ \\
\hline
\end{tabular}


Agric. Biol. J. N. Am., 2011, 2(2): 232-238

Table-2. Means comparison of characteristics by using Duncan multiple test in two wheat cultivar

\begin{tabular}{|r|r|r|r|r|r|r|r|}
\hline cultivar & $\begin{array}{c}\text { Seed } \\
\text { width }\end{array}$ & $\begin{array}{c}\text { Seed } \\
\text { diameter }\end{array}$ & $\begin{array}{c}\text { Seed } \\
\text { length }\end{array}$ & $\begin{array}{c}\text { Spike } \\
\text { length }\end{array}$ & $\begin{array}{c}\text { Awn } \\
\text { length }\end{array}$ & $\begin{array}{c}\text { Leaf area in } \\
\left(\mathrm{cm}^{2}\right) \text { plant }\end{array}$ & $\begin{array}{c}\text { Dry matter } \\
\text { in plant } \\
(\mathrm{gr})\end{array}$ \\
\hline Azar-2 & $3.03 \mathrm{a}$ & $2.75 \mathrm{a}$ & $7.12 \mathrm{~b}$ & $10.62 \mathrm{a}$ & $5.13 \mathrm{~b}$ & $817.3 \mathrm{~b}$ & $35.6 \mathrm{a}$ \\
\hline Sardare-101 & $3.02 \mathrm{a}$ & $2.76 \mathrm{a}$ & $7.63 \mathrm{a}$ & $10.56 \mathrm{a}$ & $5.35 \mathrm{a}$ & $1031.85 \mathrm{a}$ & $31.68 \mathrm{~b}$ \\
\hline
\end{tabular}

Table-3. Means comparison of characteristics by using Duncan multiple test in two year

\begin{tabular}{|r|r|r|r|r|r|r|r|}
\hline \multicolumn{1}{|c|}{ year } & $\begin{array}{c}\text { Seed } \\
\text { width }\end{array}$ & $\begin{array}{c}\text { Seed } \\
\text { diameter }\end{array}$ & $\begin{array}{c}\text { Seed } \\
\text { length }\end{array}$ & $\begin{array}{c}\text { Spike } \\
\text { length }\end{array}$ & Awn length & $\begin{array}{c}\text { Leaf area in } \\
\text { plant }\left(\mathrm{cm}^{2}\right)\end{array}$ & $\begin{array}{r}\text { Dry matter } \\
\text { in plant(g) }\end{array}$ \\
\hline 1 & $3.19 \mathrm{a}$ & $2.84 \mathrm{a}$ & $7.48 \mathrm{a}$ & $9.7 \mathrm{~b}$ & $5.7 \mathrm{a}$ & $917.46 \mathrm{a}$ & $33.87 \mathrm{a}$ \\
\hline 2 & $2.85 \mathrm{~b}$ & $2.66 \mathrm{~b}$ & $7.27 \mathrm{~b}$ & $11.47 \mathrm{a}$ & $4.7 \mathrm{~b}$ & $931.72 \mathrm{a}$ & $33.41 \mathrm{a}$ \\
\hline
\end{tabular}

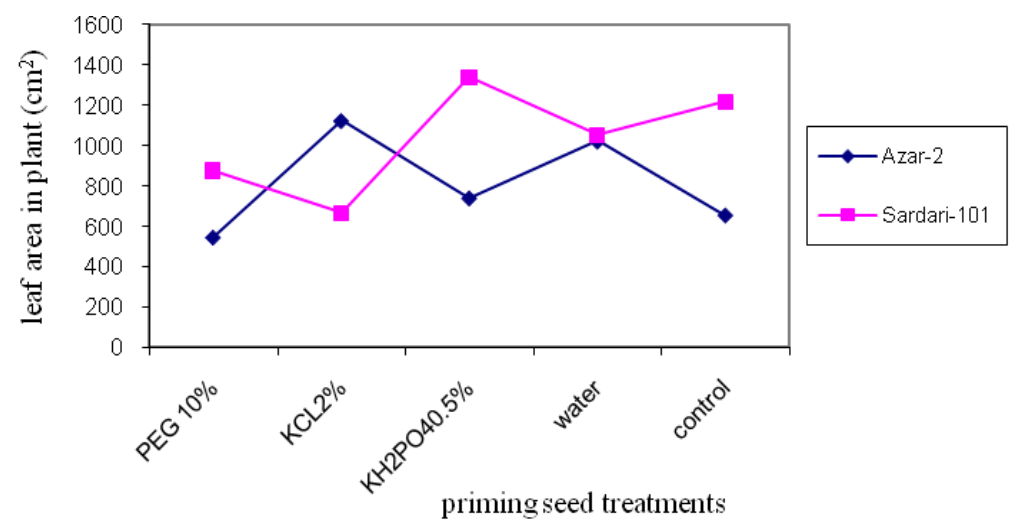

Fig1.Interaction effect of seed priming and cultivar on leaf area in plant 


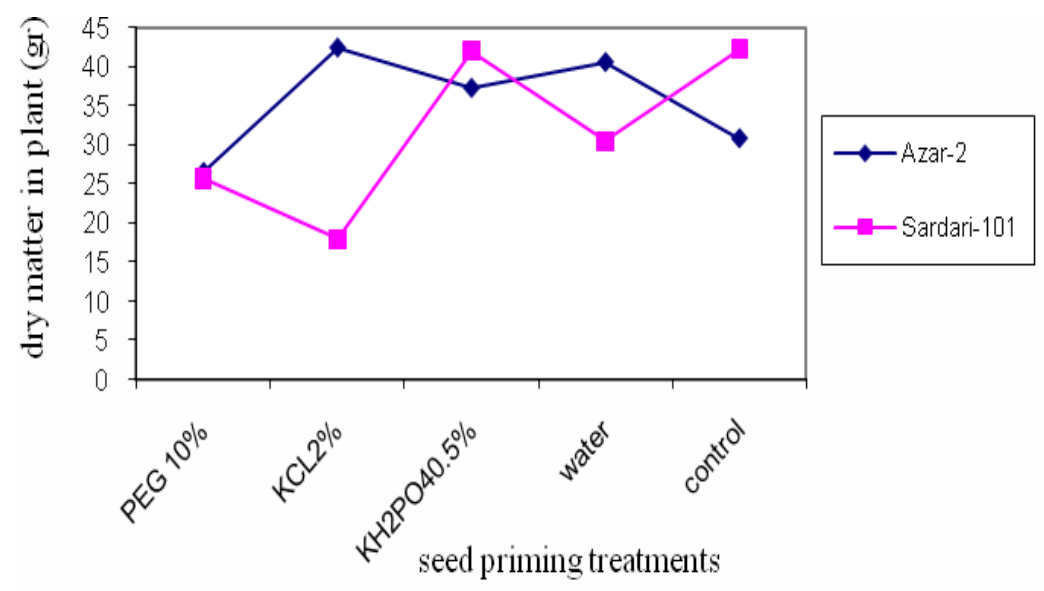

Fig2.Interaction effect of seed priming and cultivar on dry matter in plant

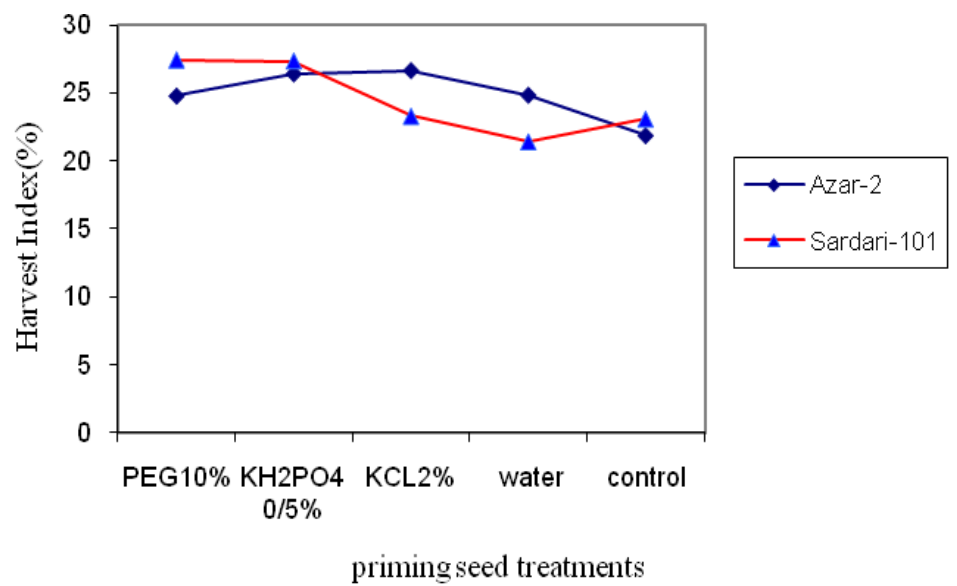

Fig3.Interaction effect of seed priming and cultivar on Harvest Index in first year 
Agric. Biol. J. N. Am., 2011, 2(2): 232-238

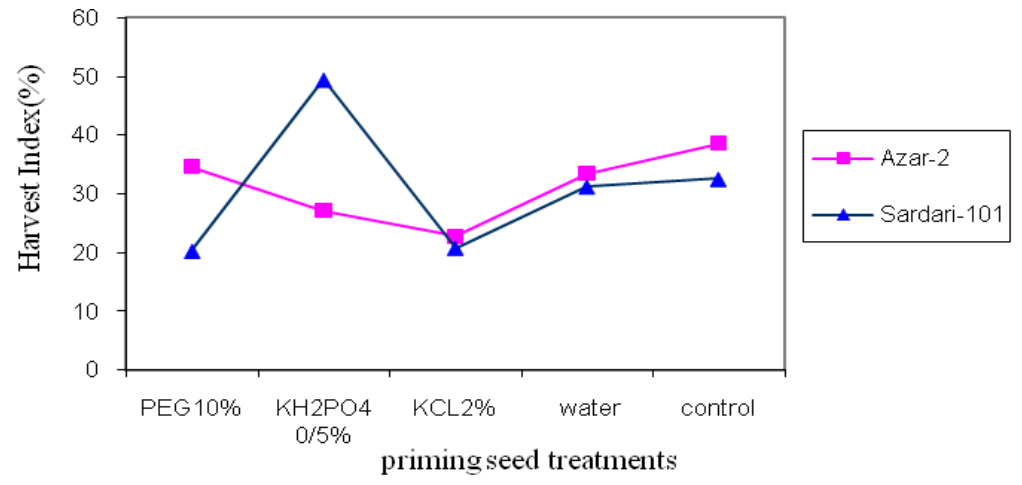

Fig4.Interaction effect of seed priming and cultivar on harvest index in second year

\section{REFERENCES}

Asgedom, $\mathrm{H}$ and Becker, M (2001).Effect of seed priming with nutrient solutions on germination, seedling growth and weed competitiveness of cereals in Eritrea In:Proc.Deutscher Tropentag 2001,Univ.Bonn and ATSAF,Margraf publishers press,Weickersheim.p.282.

Dell-Aquila, A. and Ritto, V.T (1990).Ageing and osmotic priming in wheat seeds. :Effects upon certain components of seed quality .Ann.Bot.,65:21-26.

Farooq,M., Basra ,S.M.A and Rehman Hafeez,U( 2006). seed priming enhances emergence,Yield and quality of direct-seeded rice crop management \& physiology.p.42-44

Farooq, M., Basra, S. M. A and Ahmad, N (2007). Improving the performance of transplanted rice byseedpriming. Plant Growth Regulation, 51, 129-137.

Harris ,D., Joshi, A., Khan, A.A., Gotkar, P and Sodhi, S.P( 1999).On-farm seed priming in semi-arid agriculture :development and evaluation in maze ,rice and chickpea in India using participatory methods.Exp.Agric.,37:403-415.

Harris,D., Tripathi ,R.S and Joshi, A (2000).On-farm seed priming to improve crop establishment and yield in direct seeded rice .IRRI:Inter.Worksop on dry-seeded Rice Tech.,2000.
Harris,D., Raghuwanshi, B.S, Gangwar ,J.S. and Singh ,S.C. (2001).Participatory evaluation by farmers of on-farm seed priming in wheat in india, Nepal and Pakistan.Exp.Agric.37:403-415(ISI).

Harris,D.,Raghuwanshi,B.S,Gangwar,J.S, Singh, S.C, Joshi, K.D, Rashid,Aand.Hollington, P.A(2001). Participatory evaluation by farmers of on-farm seed priming in wheat in India,Nepal, anPakistan.Exp.Agric .37, 403-415.

Henckel,P.A( 1964).Physiology of plants under grought.Annu.Rev.Plant physiol., 15:363-86.

Idris,M. and Aslam, M( 1975).The effect of soaking and drying seed before planting on the germination and growth of triticum vulgareL., under normal and saline condition.Grand.J.PL.Sci.,53:1328-1332.

Iqbal, M, Ashraf, M, Jamil A and Shafiq ur R(2006). Does seed priming induce changes in the levels of some endogenous plant hormones in hexaploid wheat plants under salt stress? Journal of Integrative Plant Biology, 48, 181-189.

Khalil,S.K., Mexal, J.G, Rehman, A, Khan, A.Z, Wahab, S, Zubair, M, Khalil I.H and Mohammad,F( 2010). Soybean mother plant exposure to temperature stress and its effect 
Agric. Biol. J. N. Am., 2011, 2(2): 232-238

on germination under osmotic

stress.Pak.J.Bot.,42(1):213-225.

Khan,A., Khalil, S.K, Khan, A.Z, Marwat K.B and Afzal. A( 2008). The role of seed priming in semi-arid area for mungbean phenol logy and yield .Pak.J.Bot.,40(6):24712480.

Khan,A., Khalil, S.K., Khan ,S and Afzal, A( 2005).Priming affects crop stand of mungbean .Sarhad J.Agric.,21:535538.

Murungu,F.S., Chiduza, C, Nyamugfata, P, Clark, L.J, Whalley ,W.R and Finch-Savage, W.E(2004).Effects of on farm seed priming on consecutive daily sowing occasions on the emergence and growth of maize in semi-arid Zimbabwe. Field Crops Res.89:49-57.

Mussa,A., Johanse, C, Kumar ,J and Harris, D( 1999).Response of chickpea to seed priming in the High Barind Tract of Bang ladesh.Inter.Chickpea and pigeoonpea Newsletter,6:20-22.
Scotte , R.K., English, S.D, Wood, S.D and Nsworth,M.H.U (1973). The yield of sugar beet in relation to weather and length of the growing season.J.Agric.Sci.,81:339-47.

Shad,K.K.,Shitab, Abdur, R, Amir, Z.K, Khalil, I.H, Said, W, Fida, M, Shaheen, N, Muhammad, Z, Sajida, P and Ahmad, K(2010).Seed priming and phosphorus application enhance phenology and dry matter production of wheat.Pak.J.Bot.,42(3):1849-1856,2010

Paul,S.R and Chodhury, A.K(1991).Effect of seed priming with potassium salts on growth and yield ofwheat under rainfed condition.Ann.Agric.Res.12:415-418.

Rafiq, S, Iqbal, T, Hameed, A , Rafiqi , Z. A and Rafiq, $N(2006)$.Morphobiochemical analysis of salinity stress response of wheat. Pakistan Journal of Botany, 38, 1759-1767.

Taiz, L and Zeiger, E(2002).Plant Physiology. 3rd Edn.,Sinaure Associates,Inc.Publishers,Su and Land, Massachusetts. 